\title{
sciendo
}

\section{Motivation as an indicator of performance and productivity from the perspective of employees}

\author{
Ana UKA \\ Beder University College, Tirana/Albania \\ auka@beder.edu.al \\ Ardita PRENDI \\ Wisdom University College, Tirana/Albania \\ ardita.prendi@gmail.com
}

\begin{abstract}
Motivation plays a crucial role on employees' performance. Though organizations have an interest in keeping the employees motivated at work, they do not always have the complete picture on what indeed motivates an employee. Scholars agree that money (including employees' wages) significantly affects employees' performance and productivity, but they do not unanimously place it among the strongest determinants of employee motivation. The main purpose of this work was to explore the factors influencing the true motivation of employees to enhance their performance and productivity at work. This study employed a quantitative research design based on data collected during the severe period of the COVID-19 pandemic. There were 110 participants, of which 38 (34.5\%) males 72 (65.5\%) females working in different companies in Albania. The results showed a moderate level of satisfaction and motivation at work and a significant correlation between the motivation and success of the company. Additionally, the data indicated that most of the participants were satisfied with the financial allowances, but that they aspired to have higher wages and better workplace conditions. Therefore, higher salaries, extra bonuses and the promotion in their role at work or recognition and appreciation seem to be very important motivational factors for the employees. Finally, this study proposes recommendations for companies on how to implement different strategies to increase employees' motivation and enhance the business effectiveness. This study analyses data collected during the global pandemic and would serve as reference for periods associated with dire financial difficulty.
\end{abstract}

Keywords: employee motivation, performance, productivity, business profits, COVID-19.

Please cite the article as follows: Uka, A., Prendi, A. (2021), "Motivation as an indicator of performance and productivity from the perspective of employees", Management \& Marketing. Challenges for the Knowledge Society, Vol. 16, No. 3, pp. 268-285, D0I: 10.2478/mmcks-2021-0016.

\section{Introduction}

Either in prosperous or challenging times of health, social, and economic changes, business managers turn their attention towards the most important organizational resource: employees. A good performing team of workers translates directly to a stronger financial 
outcome (Chi \& Gursoy, 2009; Marimuthu, Arokiasamy, \& Ismail, 2009). If employees do not feel involved and committed to work, it is hard for them to perform well and identify with the organization (Davydenko, Kaźmierczyk, Romashkina, \& Żelichowska, 2017; Ciobanu et al., 2019; Ali \& Anwar, 2021). The affinity of the employees with the company would lead to a better employee job performance and better interpersonal relationships (Wambugu, 2014; Veloso, Sousa, Au-Yong-Oliveira, \& Walter, (2021). Within an effective and successful institution, its employees can collaborate and be productive out of the common interests and benefits (Wang \& Tian, 2012). The affinity of an employee with the company depends on several factors, and researchers have worked for a long time to identify them. Some of these factors include company culture, working conditions, availability and use of resources, reward system, and so on (Cagno, Micheli, Jacinto, \& Masi, 2014). Studies consistently show that motivation is a strong predictor of job performance and productivity (Grant, 2008; Cerasoli et al., 2014; Jalagat, 2016). The more motivated the employees, the better performance and higher productivity they will demonstrate (Jalagat, 2016; Ali \& Anwar, 2021).

Motivation results from the interaction of cognition-related factors, such as the intensity of will, incentive value of the goal, and individuals' and others' expectations (Padmala \& Pessoa, 2010; Finn, 2020). Motivation has long been studied by philosophers and recently researchers argued that motivational theories should come from the foundations of psychology (Trout, 2017). Moreover, the construction of these theories should not be based only on the operational aspect of humans, but also on the principles of the functioning of the brain, thus including elements of neuroscience (Nohria et al., 2008).

Motivation makes most of the employees feel good about their jobs and perform better (Salleh et al., 2011; Jalagat, 2016), which leads them toward organizational commitment (Burton, 2012; Polatcan and Titrek, 2014; Bojnec and Tomšič, 2020). Employees become motivated through different pathways (Patterson et al., 2004) that include financial incentives for some, and recognition and appraisal by others. People who are motivated and enthusiastic about the work they do perform to the best they can, and productivity increases as well (Manzoor, 2012; Ekhsan, Aeni, Parashakti, \& Fahlevi, 2019; Rizky \& Ardian, 2019). As such, labour productivity combined with economic performance may lead to corporate sustainability in the context of a highly competitive business environment (Bojnec and Tomšič, 2020). Incentives, which are influential motivators that drive a certain behavior, are extensively used by the employers. They may take different forms, such as paid leave, bonuses, and cash. Employees need incentives and rewards from their employers to work productively (Ali \& Anwar, 2021; Ciobanu et al., 2019). Implementing a reward system and recognizing the employees help the employers identify hard-working and successful employees. As such, employees feel good and encouraged to do quality work (Rahmana, Haryoko, \& Kurniawan, 2020; Kim \& Patel, 2021).

Employees have many reasons to be motivated, which can be classified in two major sets:those related to personal goals and others related to organizational goals (Burton, 2012; Shanks, 2016). Most of the employees are motivated through the feeling of enthusiasm to successfully accomplish good work for attaining their own personal and organizational goals (Vlãdescu, 2014; Taohid, Sujai, \& Nugraha, 2021). Others prefer to be motivated by being acknowledged or recognized by the managers in front of the colleagues who might look at the employee as a role model in the workplace (Doyle, 2005; Braganza, Chen, Canhoto, \& Sap, 2021). 
Given the fact that employees' motivation impacts both their performance and productivity, this study will contribute to better understand the underlying factors that drive employees' motivation and why it is important for companies to motivate and keep their workers committed and attached to their jobs. A secondary purpose of this study was to conduct an exploratory analysis of this matter in an Albanian sample of employees working in different companies and fill in a gap in the literature focusing on employees' motivation at work in developing countries of the Western Balkans from the employees' perspective. Exploring perceptions and attitudes that employees have about the factors that motivate them at work is very crucial for employers to develop effective strategies to keep them motivated. Based on the analysis of the data, recommendations for human resource unit managers are provided. Future research may refer to the findings provided here to consider the importance of employee motivations, which may better inform business managers.

\section{Theoretical framework}

The current work is conceptualized based on four theories of motivation, which are extensively used by organizations: i) needs theory; ii) equity theory; iii) expectancy theory; and iv) job design theory. Together with the theories constructed employing only fundamentals of psychology, there are also theories that are formulated based on interdisciplinary approaches.

\section{Need-based theories}

The major need theories are i) Maslow's hierarchy of needs, ii) McClelland's acquired needs, and iii) ERG (existence, relatedness, growth) theory (Alderfer, 1969). Maslow's hierarchy of needs is a well-established motivational theory in psychology constructed into five hierarchical needs, which are relevant to business organizations and their employees' performance to attain organizational goals (Maslow, 1954; Jerome, 2013). According to this hierarchy, people are motivated to fulfill their needs starting from the most basic need to the direst ones. The basic needs are physiological and safety-related,which every organization strives to ensure. The more vital needs consist of more social ones that are related to different roles and responsibilities the organization assigns to the employees. Positive relationships established between the organization and the workers foster dire needs such as self-esteem and self-actualization among the employees. As the organization performance improves and the objectives are met, those lead to a higher employees' job satisfaction.

The five different levels of needs are described as follows: (i) physiological needs - at the base of the pyramid, there are basic physiological needs including the need for food, water, air, sleep and warmth. These are considered also as lower-level needs which, once met, the individual can jump to the next level of needs; (ii) safety needs - the second level of needs consists of individuals' desire to have control and order in their lives such as security and safety. Some examples of these needs include financial security, health and wellness, and safety against accidents/injuries; (iii) social needs - the third level of needs includes different emotional needs such as love, acceptance, and the sense of belonging. To satisfy these needs, people display different behaviors such as establishing a family and friendships and getting involved in romantic relationships, social groups, and religious 
groups, which help the individual avoid some psychological problems like depression or anxiety; an employee who is willing to satisfy social needs tries to avoid manager's appraisal in front of the peers if that is not attributed to the entire group; (iv) esteem needs - the fourth level of Maslow's hierarchy consists of the need for appreciation and respect. After the needs of the first three levels of the pyramid have been met, esteem needs start playing a more important role in motivating behavior. Individuals need to gain the respect and appreciation of others. In addition, they need to sense that their efforts are recognized and they are valued by other people. For example, an employee who is trying to satisfy esteem needs may feel recognized when the boss praises an accomplishment. Some of the behaviors that satisfy these needs are participation in different activities, job accomplishments and so on. As people satisfy such needs, they feel confident, but if they lack self-esteem, they can feel inferior. Both levels of social and esteem needs make up the psychological needs of the hierarchy; (v) self-actualization needs - at the very top of Maslow's pyramid are the self-actualization needs. Self-actualization refers to the motivation on becoming the best person one can be toward both the self and others (Maslow, 1954). This level of needs includes the realization of one's full potential. Maslow described this need as a value-based system and as an explicit motive when considering it in relation to motivation. People who are motivated to attain this goal try to make sense how their needs, relationships and the sense of self are manifested through their behaviors. Maslow's theory of needs may be applied to the roles of organizational management in increasing employees' motivation and improving their performance (Jerome, 2013).

Several theories that explain how motivation affects one's behavior have been proposed in the literature and one of the most referred is the Socially Acquired Needs Theory (McClelland, 1987). In the focus of this theory is the motive, which refers to the needs, desires and the inner-forces that drive one's behaviors. The major needs that drive one's behavior have been analyzed much earlier in the literature (McClelland, 1961) and they currently constitute three categories including the need for achievement (nAch), the need for power (nPow), and the need for affiliation (nAff). The degree of each of these major needs depends on social status, age, sex and also affect differently the motivation in everyday life (Wiley, 1997).

Need for Achievement (nAch) is described as the desire to perform something difficult. An achievement is something that someone has succeeded in doing, especially after a lot of effort, as defined in Collins online dictionary. Employees who are highly achievement-motivated are driven by the desire to work on tasks of moderate difficulty where they expect to receive feedback about their work. This theory claims that people with high nAch are motivated by accomplishing a goal. Next, McClelland (1961) describes the need for power (nPow) as a desire to influence the others. Power has been defined as the ability to control other's behaviour in Oxford's online dictionary. Other scholars defined the nPow as the unconscious concern to have authority and responsibility for others (Lussier and Achua, 2007, 2015; Daft, 2008). Employees who are strongly powermotivated, display behaviors driven by the desire to influence, guide or support others. They value the work and discipline. The third type of need, as indicated by McClelland, is the Need for Affiliation (nAff). To affiliate means to be connected to a political party, religion, or a larger organization. McClelland (1961) defined affiliation as developing, maintaining or re-establishing a positive emotional relationship with another person. Need for affiliation is expressed as the desire to stay closely connected to other people, avoid 
conflicts and build long lasting relationships ( Lussier and Achua, 2007, 2015; Blay, Keshet, Friedman, \& Gilboa-Schechtman, 2021;). Employees who are highly affiliation-motivated are driven by the desire to establish and maintain social relationships (Kahil, 2021). They value the sense of belonging to a group and feel loved and approved. They are not considered to be effective managers, as the need to be liked by others might affect their decision-making and objectivity. But they are considered to be good collaborators and team players.

The acquired-needs theory claims that all people are motivated by all these needs in various degrees and amounts. According to this theory, employees are more likely to be affiliation-motivated though sometimes, their affiliation needs are not met. McClelland also suggests that top leaders have a high need for power motivation, and those who are achievement-motivated can only become good managers.

\section{Equity Theory}

Equity theory has been used over the past five decades to explain a broad range of social behavior including social protest, coalition movements, child development (Adams, 1963). This theory explains the motivation based on the expectation of fair and equal rewards to be received by all the employees rather than the quality and the quantity of individual rewards (Adams and Freedman, 1976). Equity theory acquires more ground as the common social behavior of expecting equal benefits is supported by legislation that expects from companies with governmental contracts to practice pay transparency (Trotter et al., 2017). The passing of similar laws raises the awareness on decreasing the pay gap between men and women and between different ethnic groups. The equity theory assumes that individuals build their expectations based on relative skills, previous education level and training attained and then expect that the benefits would be directly related with the professional status. Employees develop their expectations based on equity during socialization with other colleagues at work and close family circle. Companies have been promoting motivation through equity theory by offering several benefits openly and in a transparent way in order to retain their skilled employees. Unexpectedly, Silicon Valley companies that offer more benefits than many non-Silicon Valley ones have often reported lower retention rates than other companies (Sun, 2016). This points to a more complex model of equity theory that needs more research. It could be that highly skilled individuals at earlier stages of professional life have different equity sensitivity.

\section{Expectancy theory}

Expectancy theory of motivation evolved initially from the work of Georgopoulos, Mahoney and Jones (Georgopoulos et al., 1957) and was finally formulated by Vroom (Vroom, 1964). It states that individuals develop goals as a result of certain expectations. This theory has been subject to constant pressure discouraging its wide acceptance since early on and has been analyzed from different perspectives until recently in the literature (Kiatkawsin and Han, 2017; Lloyd and Mertens, 2018). Expectancy theory is based on three constructs: i) valence, ii) expectancy and iii) instrumentality. Valence is defined as the emotional orientation toward rewards for the work done. Expectancy is defined as the feeling developed on whether an outcome will be fulfilled or not. Instrumentality is the belief that the benefits, other than the salary, will be received once the expected work performance is demonstrated. The values that originate from the expectancy theory are used in models of 
entrepreneurial motivation and self-employment during economic crises (Barba-Sánchez and Atienza-Sahuquillo, 2017). They found that motivation plays an equal role with the financial ability on the establishments of new companies. Vrooms model has been developed further in the literature, and new directions for developments are also proposed. For example, Porter and Lawler attempted very early to identify the source of people expectancy and the link between effort and performance. They confirmed a moderation model where the effort and performance were moderated by individuals' abilities (Porter and Lawler, 1968). Considering that social patterns and expectations change with time, one would wonder whether the expectation model is still valid. New research after identifying the effect of social interaction calls for the inclusion of social variables in the expectancy model (Lloyd and Mertens, 2018).

\section{Job design theory}

The main models that are included in the job design theory are motivational- hygiene and job characteristic model. The motivational-hygiene model was developed by Herzberg to understand both employee satisfaction and motivation at workplace. He was interested in learning how employees' attitudes influence motivation by investigating the way employees felt in relation to work situations. This is also known as a two-factor theory whose findings contributed to the development of motivational practices in companies. This model indicates that employees become motivated as they work in an enjoyable and positive work environment where they can develop, succeed and show accountability and progress in the company. Herzberg (1987) found out that certain job factors classified as motivator and hygiene ones are related to both job satisfaction and dissatisfaction as indicated also by Ratzburg (2003). The hygiene factors including physiological, love and safety needs correspond with Maslow's hierarchy of needs. The lack of such factors in a workplace does not necessarily lead to low levels of motivation, but it may result in job dissatisfaction. Among such factors are interpersonal relationships with colleagues and supervisors, job security, work conditions, salary, technical support, and so on, considered as hygiene factors, which are necessary to maintain a certain level of satisfaction, but may also result in dissatisfaction. However, the presence of these conditions is not directly related to motivation (Dartey-Baah \& Amoako, 2011). Next, Herzberg indicated that the motivator factors are more intrinsic in nature and they are related to the physiological needs for development and recognition. The lack of these factors does not necessarily cause dissatisfaction, but when present, they lead to high levels of motivation, which results in high performance. Motivator factors include success, progress, recognition and the opportunity for personal growth and accountability. Herzberg theory claims that people are given the opportunity to be responsible for controlling their work resulting in high motivation and satisfaction. Employers usually pay attention to hygiene factors to motivate their employees, while in fact they should invest in increasing job satisfaction related to work environment. Employees need to be treated with respect and dignity and given the opportunity for growth and achievement.

\section{Importance of motivation in the workplace}

Motivation plays a significant role in the profits and accomplishment of an organization. It is the key element that influences human capital, which is the main asset of a company. The concept of motivation has its roots in the word of motive, which is related to desires, wants, 
and needs of individuals. Motivation is described as a drive that explains or controls the human behavior (Dalton, 1974; Uka, 2012). Employee motivation is a strategy used by many organizations towards the employees consisting in providing them with cash, rewards, and other incentives to reach organizational goals. It energizes the employee to work effectively and productively in a self-determined way (Cole, 2009; Ali \& Anwar, 2021). This energy is released from either external or internal sources, which leads the employee to be either extrinsically or intrinsically motivated. Identifying the way employees get motivated leads the employers to adapt motivational tactics accordingly.

Previous studies have confirmed that motivation affects employee performance and job satisfaction (Rao Subba, 2005; Springer, 2011; Edirisooriya, 2014; Ali et al., 2016; Tasman, Siregar, \& Nasution, 2021). Colquitt et al (2002) view job performance as a set of employee's behaviors that have a positive or negative effect on the achievement of organizational objectives. Job performance includes behaviors that are within the control of employees. Research shows that motivation encourages the employees or workers of the organization to be committed to their work and roles (David et al., 2004; Kuvaas and Dysvik, 2009; Azar and Shafighi, 2013). Employee motivation as an important indicator of performance results in several benefits for companies as well. Some of these benefits are: human capital management; meeting company's and personal goals; greater employee satisfaction and efficiency; and better work environment (Ganta, 2014; Shin \& Hur, 2021).

Workers are the human resource to the organization and their success or failure has a huge impact on the organization. So, the employers and especially managers should be careful with the way how they treat and approach resources (Gričar et al., 2020). Those employees who are motivated are also self-determined towards the achievement of organizational goals (Schulz and Steyn, 2003; Idiegbeyan-Ose et al., 2019). Studies show that employees play a crucial role in developing organizational creativity and innovation (Bojnec \& Tomsic, 2020; Ottenbacher and Harrington, 2007; Titrek, 2015). These innovative workers provide the organization with economic benefit. Motivation influences an individual's performance in the organization by providing or giving a different kind of incentive and rewards, which are essential for employees to shift from dissatisfaction to pleasure. Reasonable wages or other benefits are also appreciated elements and play a significant role to improve workers' performance and productivity of the organization. The performance of individuals is related to what a person does and what they do not do. It is the usual behavior that employees display in associations with their work (Dizgah et al., 2012).

\section{Employees' motivational factors}

Employee motivation has been a topic of interest of past studies for almost a century dating back to the 1940s when scientists were seeking answers to the question, "Why do workers work?" If a business organization is aware of what drives employees to work, it is easier to motivate them to be productive (Kovach, 1987). The way employees feel about their job and the working environment determines how motivated they are. It has been welldocumented in the literature that there is a positive association between job satisfaction, productivity and work performance (Ek and Mukuru, 2013; Shahzadi et al., 2014; Asim, 2013; Bojnec \& Tomsic, 2020). The more satisfied the workers are, the more motivated they feel, the better they perform, thus leading to higher productivity. Griffin (1990) indicated that the strongest determinants of employee performance appear to be as follows: i) ability, 
ii) the work environment, and iii) motivation. The first two can be easily resolved whenever a problem arises, but when it comes to motivation, that is a more complex one, which is more dependent on the employees who should report motivational problems. As such, employers can modify certain factors, such as work conditions, monthly payments, or recognition strategies towards employees.

Factors such as high salaries (Harrison et al., 1996; Trevor et al., 1997; Trank et al., 2002), positive working climate, and good interpersonal relationships (Ganta, 2014) are not among the strongest determinants of staff motivation, but their lack leads to employee dissatisfaction, which negatively influences motivation. Other scholars indicate that true motivation comes from having a sense of belonging to the organization and the desire to have high achievement and responsibility (Gayathiri et al., 2013). Employers should be aware of whether they are creating a motivational climate and, if needed, how they can improve it (Olcum and Titrek, 2015). Both employees and managers should collaboratively contribute to the creation of an atmosphere characterized by good organizational communication (Patterson et al., 2004; Titrek, 2009; Vozza, 2018; Indrasari et al., 2019). In a study conducted by Kovach (1995), 1,000 employees and 100 of their bosses were asked to list the things that they believe motivate employees. Managers thought employees would be highly motivated by good payments and safety at work, while employees reported factors such as participating in interesting work, feeling recognized at work and "being in on things." What managers thought would be important for the employees, in fact were lower on the list. Kovach's findings seem to be consistent with other well-established motivational theories, such as Maslow's hierarchy of needs, which posits that after the basic needs are met, people become more motivated by higher factors, such as psychological needs, including autonomy, self-esteem and self-actualization.

\section{Method}

\section{Sample and data collection procedure}

The total number of participants was $\mathrm{N}=110$, including employees working in different companies mainly located in Tirana, the capital city of Albania. A convenient sampling technique was used to recruit the participants in this study. They reported a work experience ranging from one to twenty years. In total, there were $n=38$ males $(34.5 \%)$ and $\mathrm{n}=72$ females (65.5\%). The data were collected during April and May 2020, the most intensive period of the Covid-19 pandemic in Albania. The questionnaire used in this study was implemented on Google forms and the link was electronically distributed to the participants to obtain information about their perceptions on the work needs, their common problems at work, and motivational factors. Participants were free to answer all the questions, while they were assured about the anonymity and confidentiality of the data.

\section{Measurement tool}

In this study, a quantitative research design was employed. The survey aimed at obtaining information about the current situation related to the employees' motivational factors, their needs at work and perceptions about the role of an I/O psychologist in the company. The survey consisted of two parts. The first part of the questionnaire included demographic questions, and the second part included questions about motivation at work, work conditions, the voice of the employees in the decision-making process and other needs. The 
survey included items on a Likert-type scale (ranging from 1 "never" to 5 "always") and close-ended questions with options "yes" or "no".

\section{Measures}

Employee's motivational factors at workplace. This scale included four questions as follows: "Do you feel appreciated in your company?", "Are your opinions heard at work?", "Do you have the freedom to express your opinion?" and "Do you feel safe at work?" .These items were on a Likert-type scale (ranging from 1 "never" to 5 "always"). The scale reliability analysis provided a Cronbach alpha, $\alpha=.90$.

Employees' needs at work. This variable was measured by asking the respondents three questions like: "Do you need better work conditions?", "Do you need more advanced technology at work?", and "Do you need more recognition by the supervisors at work?". The items were on a Likert-type scale (ranging from 1 "never" to 5 "always"). The reliability analysis was conducted and it revealed a Cronbach alpha equal to 0.74 .

Employees' knowledge about the role of an organizational psychologist at the company. This measure consisted of close-ended questions that could be answered with a "yes" or "no" such as: "Does your company have an organizational psychologist?" or "Is there a human resources unit in your company?" Some companies are part of holding companies and the human resources services are controlled by units out of individual companies.

Interview questions were open-ended questions used to obtain information related to their opinions about different factors related to their experience with the company, such as "What are the most common problems you encounter in your company?" or "What do you know about the importance of employee motivation and does your company organize workshops to train the employees?"

The data were validated by conducting a principal axis factor analysis to check whether they fit into the two constructs to confirm the support for the construct validity of the two scale measures in this sample. Two factors were requested where the items were designed to index two constructs: motivational factors and needs at work. After rotation, the first factor accounted for $41.4 \%$ of the variance, and the second factor accounted for 22.8\%. The first factor, which seems to index employees' motivational factors, has strong loadings above .70 on the first four items. The second factor, which seemed to index employees' needs at work, had high loadings above .55 on the next three items. A test of normality was conducted for all study variables where the descriptive statistics showed that the skewness values range between -1 and 1 . This analysis indicates that the variables are at least approximately normally distributed.

\section{Data analysis}

Data was analyzed by using the Statistical Program for Social Sciences (SPSS) version 21.0. The reliability statistics were used to assess the internal consistency reliability with Cronbach's alpha for the items of each scale of the study variables. Then, an exploratory factor analysis was conducted to indicate the construct validity of the questionnaire used for the aim of this study. Frequency distributions and descriptive analysis were used to explore employees' motivational factors, their basic needs at work, and perceptions about the role of an I-O psychologist in the company. Then, the Bivariate Pearson Correlation analysis was used to investigate the relationship between the employees' motivation and the success of the company. 


\section{Results}

As shown in Table 1, descriptive analysis revealed the means, standard deviations, range, skewness and kurtosis for all the items included in that scale. To investigate employees' perceptions about the motivational factors, descriptive analysis was conducted where the values of skewness and kurtosis indicate that the items of this scale are normally distributed. They have means ranging from 3.49 to 3.77 with a standard deviation of 1.20 . Referring to the minimum and the maximum values of this variable, on average most of the employees have reported that their voices were heard, they feel free to express their opinion, they feel safe at work and they feel appreciated by their bosses at a moderate level.

Table 1. Employees' Motivational Factors, ( $N=110)$

\begin{tabular}{|l|l|l|l|l|}
\hline Variable & M (SD) & Range & Skewness & Kurtosis \\
\hline 1. Employees' voice heard & $3.49(1.21)$ & $1-5$ & -0.42 & -0.81 \\
\hline 2. Freedom to express opinion & $3.77(1.20)$ & $1-5$ & -0.65 & -0.61 \\
\hline 3. Employees' safety at work & $3.76(1.20)$ & $1-5$ & -0.61 & -0.62 \\
\hline 4. Employees feeling appreciated & $3.69(1.18)$ & $1-5$ & -0.67 & -0.44 \\
\hline
\end{tabular}

Source: Authors' own research.

Regarding the employees' basic needs at the workplace, most of the participants reported (ranging from 1 - "Not agree at all" to 4 - "Totally agree") that among the most basic needs of the Albanian employees are: 1. Better work conditions; 2. More advanced technology; and 3. More appreciation from the supervisors. Descriptive analysis shows the values of the means and standard deviations and it indicates that the data are normally distributed.

Table 2. Employees' basic needs at workplace, $(N=110)$

\begin{tabular}{|l|l|l|l|l|}
\hline Variable & M (SD) & Range & Skewness & Kurtosis \\
\hline 1. Better Work Conditions & $3.15(0.88)$ & $1-4$ & -0.79 & -0.12 \\
\hline 2. More Advanced Tech. & $3.77(1.20)$ & $1-4$ & 0.10 & -0.84 \\
\hline $\begin{array}{l}\text { 3.More appreciation from } \\
\text { supervisors }\end{array}$ & $3.76(1.20)$ & $1-4$ & -0.94 & -0.06 \\
\hline
\end{tabular}

Source: Authors' own research.

Then, the Bivariate Pearson Correlation analysis showed that there is a significant positive correlation between employees' motivation and their perceptions about the role of employees' motivation on the success of the company, $r(110)=.28, p<.001$, which is considered a medium effect size (Cohen, 1988).

Table 3. Intercorrelation between two main study variables $(n=110)$

\begin{tabular}{|l|l|l|}
\hline Variable & $\mathbf{1}$ & $\mathbf{2}$ \\
\hline 1. Employees' Motivation &.. & $0.28^{*}$ \\
\hline 2. Company's success &.. &.. \\
\hline${ }^{*} \boldsymbol{p}<.001$ & & \\
\hline
\end{tabular}

Source: Authors' own research. 
Regarding employee's information about the presence of a human resources specialist in their workplace, as it is noted in Table 4, 63.6\% of participants (70 out of 110) reported that there is a human resources unit in their company and $36.4 \%$ of the participants (40 out of 110) indicated that there is no human resources unit in their company. This finding indicates that a relatively large number of the Albanian companies do not pay attention to the importance of the presence of a human resources representative in a workplace.

Table 4. Employees' awareness about the presence of the I/O psychologist, $(N=110)$

\begin{tabular}{|l|l|l|}
\hline & Frequency & Percent \\
\hline Yes & 70 & $63.6 \%$ \\
\hline No & 40 & $36.4 \%$ \\
\hline \multicolumn{2}{|c|}{ Source: Authors' own research. }
\end{tabular}

Finally, the respondents were asked about their knowledge on the role of an I/O psychologist in the company and their answers are reported in Table 5. A share of 57.3\% of the respondents (63 out of 110) claimed that they were aware about the role of an organizational psychologist in a company and $42.7 \%$ of the respondents (47 out of 110) reported that they were not aware about the role of an organizational psychologist.

Table 5. Employees' awareness about the role of the I/O psychologist, $(N=110)$

\begin{tabular}{|l|l|l|}
\hline & Frequency & Percent \\
\hline Yes & 63 & $57.3 \%$ \\
\hline No & 47 & $42.7 \%$ \\
\hline
\end{tabular}

Source: Authors' own research.

\section{Results from the interview questions}

Based on the interviews conducted with the participants, it was observed that the most important concerns in their companies were low wages, extended working hours, delays in monthly payments, and lack of job description and proper coordination. These results are in line with common expectations of the authors and also with the previous reports in the literature (Zahaj et al., 2016). Their comparisons were mainly with the working conditions in the Western Balkan countries. The participants reported different motivational methods used by their companies. Some companies accomplish this by: i) increasing the wage, ii) offering appropriate trainings for their professional development, iii) providing periodic rewards and iv) promoting to higher positions. Among the different motivational strategies initiated by the companies, the least reported one was the organization of trainings and workshops. Finally, the participants reported that their productivity was higher when they were motivated in their workplace and this has directly affected the companies' overall financial performance.

\section{Discussion and Conclusions}

The findings reported here add more by contributing to a gap in the existing literature on the motivational factors and needs of the employees working in companies in developing countries in Eastern Europe. The fact that the data collection was conducted during a global economic downturn should point to conclusions that are specific only to times associated with extreme financial difficulties. Similar to many countries around the world and in the 
Western Balkan, the unexpected circumstances have created a traumatic situation. Moreover, the weaker national economic power, when compared to many European Union countries, has pushed many private companies to unprecedented measures including layoffs, pay cuts, and delayed wages. Small glimpses of hope following the government promises at the beginning of the pandemic could not survive the unexpected length of the lockdown. In these conditions, the responses of the participants would expectedly be leaning more toward the financial aspect of motivation. These findings support and expand on existing hypotheses regarding the importance of employee motivation to increase business productivity and job performance. The results showed that the Albanian employees were satisfied at an average level in terms of the four major factors analyzed here. The 'employee's voice heard' was reported as the weakest factor whereas the 'employee's safety at work' and 'freedom to express opinion were reported as the strongest motivational factors. Based on this result, the companies could improve further by having the employee's voices heard more as this would create a positive and supportive atmosphere at the workplace. In this type of atmosphere, the employees feel more motivated and productive (Gayathiri et al., 2013; Indrasari et al., 2019). It is important to note that the data is collected from the employees of the largest companies in Albania and the participants' source of motivation could be different from the factors that motivate the majority of Albanian workers. A similar difference among workers with different skillsets is observed when comparing professionals working in high-technology companies with professionals working in other jobs, including manufacturing and service provision (Sun, 2016).

Next, the analysis showed the employees' relative preferences of different needs at work in order to feel motivated. The results indicated that 'better work conditions' is a basic need (Maslow need theory), and 'more advanced technology', together with 'greater appreciation from supervisors' were among the fundamental needs of the employees. This finding is supported by other studies that reported that employees need recognition from their employers to produce quality work (Polatcan and Titrek, 2014; Ciobanu et al., 2019). By contrast, the literature shows that extra rewards, higher wages or even empathy toward their personal problems seem to be important indicators of employee motivation (Kovach, 1987). These needs that were reported in this study can be explained by the need theory and expectancy theory.

Another finding of this study revealed that there is a positive relationship between employee motivation and the success of the company. The more motivated the employees are, the better they perform at work, thus increasing the financial stability of the company. This finding is supported by other studies claiming that there is a positive association between employee motivation, job satisfaction, productivity, corporate sustainability, and labor performance (Asim, 2013; Bojnec \& Tomsic, 2020; Ek and Mukuru, 2013; Shahzadi et al., 2014).

The analysis of the qualitative data found out that employees feel satisfied and motivated when they receive extra bonuses, when they are promoted in their role and responsibilities, and when they feel appreciated by others and especially by their supervisors. These findings are in line with the work conducted by David et al (2004), who agreed that assigning new roles and responsibilities to people leads them to be motivated to work harder. The finding that pay raise constitutes an important factor of motivation for the Albanian employees is also supported by the literature showing that salary is an 
important indicator of employees' satisfaction and performance and hence, business productivity (Gričar, Šugar, \& Bojnec, 2020; Trank et al., 2002).

This study comes along with a few limitations. First, due to the official COVID-19 lockdown, both the quantitative and the qualitative data for this study were collected online, which means that the researcher was not able to interview the participants on a face-to-face meeting to get a broader view about their perceptions on motivational factors and needs at work. Second, again, due to the situation related to the COVID-19 pandemic, the sample was limited geographically to respondents who work in some big companies located mostly in the capital city of Albania. Therefore, the sample does not represent the entire population and the generalization of the results would be limited.

\section{Implications}

These findings may have implications for business organizations, which should pay attention to the importance of employee motivation to increase productivity and improve performance. Companies and especially the managers should be able to create a positive and supportive working atmosphere where the employees' work is highly appreciated, keep good working conditions, adequately mentor their staff according to the intentions of the organization, and provide freedom to express their opinions; these have been identified among some of the needs reported by the respondents in this study. The findings also suggest that the management should develop a proper system of rewards and recognition, implement it coherently, and ensure equity to avoid the de-motivation of the staff. In this way, the organization can attain organizational goals and increase profits.

Finally, this study suggests that more research needs to be conducted to explore other motivational factors and links between other variables related to motivation and employees' performance. Future studies should focus on understanding the most important needs and factors, which may influence not only business productivity, but also employees' working skills. Considering that the motivational factors identified by the employees can be explained by the need theory and expectancy theory, research should focus on models that are based on these two theories. These models should also include variables related to social behavior.

\section{Author Contributions}

AU designed the study, analysed the data and wrote the paper. AP contributed on writing the paper.

\section{Acknowledgments}

We thank Olivia Andoni for the help during the data collection. 


\section{References}

Adams, J. S. (1963). Towards an understanding of inequity. J. Abnorm. Soc. Psychol. 67, 422.

Adams, J. S., and Freedman, S. (1976). "Equity theory revisited: Comments and annotated bibliography," in Advances in experimental social psychology (Elsevier), 43-90.

Alderfer, C. P. (1969). An empirical test of a new theory of human needs. Organ. Behav. Hum. Perform. 4, 142-175.

Ali, B. J., \& Anwar, G. (2021). The mediation role of change management in employee development. Ali, BJ, \& Anwar, G.(2021). The Mediation Role of Change Management in Employee Development. International Journal of English Literature and Social Sciences, 6(2), 361-374.

Ali, A., Bin, L. Z., Piang, H. J., and Ali, Z. (2016). The Impact of Motivation on the Employee Performance and Job Satisfaction in IT Park (Software House) Sector of Peshawar, Pakistan. Int. J. Acad. Res. Bus. Soc. Sci. 6, 297-310. doi:10.6007/ijarbss/v6-i9/2311.

Asim, M. (2013). Impact of Motivation on Employee Performance with Effect of Training : Specific to Education Sector of. Int. J. Sci. Res. Publ. 3, 1-9. Available at: http://www.ijsrp.org/research-paper-0913/ijsrp-p21120.pdf.

Azar, M., and Shafighi, A. A. (2013). The Effect of Work Motivation on Employees' Job Performance (Case Study: Employees of Isfahan Islamic Revolution Housing Foundation). Int. J. Acad. Res. Bus. Soc. Sci. 3, 432-445. doi:10.6007/ijarbss/v3i9/231.

Barba-Sánchez, V., and Atienza-Sahuquillo, C. (2017). Entrepreneurial motivation and selfemployment: evidence from expectancy theory. Int. Entrep. Manag. J. 13, 1097-1115.

Blay, Y., Keshet, H., Friedman, L., \& Gilboa-Schechtman, E. (2021). Interpersonal motivations in social anxiety: Weakened approach and intensified avoidance motivations for affiliation and social-rank. Personality and Individual Differences, 170, 110449.

Bojnec, Š., and Tomšič, N. (2020). Corporate sustainability and enterprise performance. Int. J. Product. Perform. Manag.

Braganza, A., Chen, W., Canhoto, A., \& Sap, S. (2021). Productive employment and decent work: The impact of AI adoption on psychological contracts, job engagement and employee trust. Journal of business research, 131, 485-494.

Burton, K. (2012). A study of motivation: How to get your employees moving. Management $3,232-234$.

Cagno, E., Micheli, G. J. L., Jacinto, C., \& Masi, D. (2014). An interpretive model of occupational safety performance for Small-and Medium-sized Enterprises. International Journal of Industrial Ergonomics, 44(1), 60-74.

Cerasoli, C. P., Nicklin, J. M., and Ford, M. T. (2014). Intrinsic motivation and extrinsic incentives jointly predict performance: A 40-year meta-analysis. Psychol. Bull. 140, 980.

Chi, C. G., \& Gursoy, D. (2009). Employee satisfaction, customer satisfaction, and financial performance: An empirical examination. International Journal of Hospitality Management, 28(2), 245-253.

Ciobanu, A., Androniceanu, A., and Lazaroiu, G. (2019). An integrated psycho-sociological perspective on public employees' motivation and performance. Front. Psychol. 10, 17. doi:10.3389/fpsyg.2019.00036.

Cohen, J. (1988). Statistical power analysis for the behavioural sciences, 2nd edn.(Hillsdale, NJ: L. Erlbaum Associates). 
Cole, N. (2009). Workplace Romance: A Justice Analysis. J. Bus. Psychol. 24, 363-372. doi:10.1007/s10869-009-9117-1.

Colquitt, J. A., Noe, R. A., and Jackson, C. L. (2002). Justice in teams: Antecedents and consequences of procedural justice climate. Pers. Psychol. 55, 83-109.

Daft, R. L. (2008). New Era of Management, 2nd International Edition. Thompson SouthWestern, Mason.

Dalton, E. M. (1974). Management: principles and practices.

David, S., Louis, A. M., and Micheal, I. M. (2004). Why Your Employees Are Losing Motivation. Work. Knowl. Bus. leaders 4, 1-4.

Davydenko, V., Kaźmierczyk, J., Romashkina, G. F., \& Żelichowska, E. (2017). Diversity of employee incentives from the perspective of banks employees in Poland-empirical approach. Entrepreneurship and Sustainability Issues, 5(1), 116-126.

Dizgah, M. R., Chegini, M. G., and Bisokhan, R. (2012). Relationship between job satisfaction and employee job performance in Guilan public sector. J. Basic Appl. Sci. Res. 2, 17351741.

Doyle, S. (2005). The Manager's Pocket Guide to Motivating Employees. Human Resource Development.

Edirisooriya, W. A. (2014). Impact of Rewards on Employee Performance : With Special Reference to ElectriCo .311-318.

Ek, K., and Mukuru, E. (2013). Effect of motivation on employee performance in public middle level Technical Training Institutions in Kenya. Int. J. Adv. Manag. Econ. 2, 7382.

Ekhsan, M., Aeni, N., Parashakti, R., \& Fahlevi, M. (2019, November). The Impact Of Motivation, Work Satisfaction And Compensation On Employee's ProductivityIn Coal Companies. In 2019 1st International Conference on Engineering and Management in Industrial System (ICOEMIS 2019) (pp. 406-415). Atlantis Press.

Finn, B. (2020). Exploring interactions between motivation and cognition to better shape self-regulated learning. Journal of Applied Research in Memory and Cognition, 9(4), 461-467.

Ganta, V. C. (2014). Motivation in the workplace to improve the employee performance. Int. J. Eng. Technol. Manag. Appl. Sci. 2, 221-230.

Gayathiri, R., Ramakrishnan, L., Babatunde, S. A., Banerjee, A., and Islam, M. Z. (2013). Quality of work life-Linkage with job satisfaction and performance. Int. J. Bus. Manag. Invent. 2, 1-8.

Georgopoulos, B. S., Mahoney, G. M., and Jones Jr, N. W. (1957). A path-goal approach to productivity. J. Appl. Psychol. 41, 345.

Grant, A. M. (2008). Does intrinsic motivation fuel the prosocial fire? Motivational synergy in predicting persistence, performance, and productivity. J. Appl. Psychol. 93, 48-58. doi:10.1037/0021-9010.93.1.48.

Gričar, S., Šugar, V., and Bojnec, Š. (2020). The missing link between wages and labour productivity in tourism: evidence from Croatia and Slovenia. Econ. Res. Istraživanja, $1-22$.

Griffin, R. W. (1990). Management. Houngthon Mifflin Company.

Harrison, D. A., Virick, M., and William, S. (1996). Working without a net: Time, performance, and turnover under maximally contingent rewards. J. Appl. Psychol. 81, 331. 
Idiegbeyan-Ose, J., Opeke, R., Aregbesola, A., Owolabi, S., and Eyiolorunshe, T. A. (2019). Relationship between motivation and job satisfaction of staff in private university libraries, Nigeria. Acad. Strateg. Manag. J. 18.

Indrasari, M., Syamsudin, N., Bambang Purnomo, R., and Yunus, E. (2019). Compensation, organizational communication, and career path as determinants of employee performance improvement. Humanit. Soc. Sci. Rev. 7, 956-961. doi:10.18510/hssr.2019.74130.

Jalagat, R. (2016). Job performance, job satisfaction, and motivation: A critical review of their relationship. Int. J. Adv. Manag. Econ. 5, 36-42.

Jerome, N. (2013). Application of the Maslow's hierarchy of need theory; impacts and implications on organizational culture, human resource and employee's performance. Int. J. Bus. Manag. Invent. ISSN (Online 2, 23198028.

Judiesch, M. K. (1995). The effects of incentive compensation systems on productivity, individual differences in output variability and selection utility.

Kahil, B. (2021). Motivation and privacy role in knowledge sharing during Pandemic 2020: A study of enterprise social system use in Malaysian SMEs. Journal of Digitovation and information system (JDIIS), 1(1), 28-42.

Kiatkawsin, K., and Han, H. (2017). Young travelers' intention to behave proenvironmentally: Merging the value-belief-norm theory and the expectancy theory. Tour. Manag. 59, 76-88.

Kim, K. Y., \& Patel, P. C. (2021). A multilevel contingency model of employee ownership and firm productivity: The moderating roles of industry growth and instability. Organization Science, 32(3), 625-648.

Kovach, K. A. (1987). What motivates employees? Workers and supervisors give different answers. Bus. Horiz. 30, 58-65.

Kovach, K. A. (1995). Employee motivation: Addressing a crucial factor in your organization's performance. Employ. Relat. Today 22, 93-107.

Kuvaas, B., and Dysvik, A. (2009). Perceived investment in employee development, intrinsic motivation and work performance. Hum. Resour. Manag. J. 19, 217-236. doi:10.1111/j.1748-8583.2009.00103.x.

Lloyd, R., and Mertens, D. (2018). Expecting more out of Expectancy Theory: History urges inclusion of the social context. Int. Manag. Rev. 14, 28-43.

Lussier, R. N., and Achua, C. F. (2007). Effective leadership. Thomson South-Western.

Lussier, R. N., and Achua, C. F. (2015). Leadership: Theory, application, \& skill development. Nelson Education.

Marimuthu, M., Arokiasamy, L., \& Ismail, M. (2009). Human capital development and its impact on firm performance: Evidence from developmental economics. Journal of international social research, 2(8).

Manzoor, Q.-A. (2012). Impact of employees motivation on organizational effectiveness. Bus. Manag. Strateg. 3, 1-12.

Maslow, A. H. (1954). Motivation and personality Harper and Row. New York, NY.

McClelland, D. (1961). David C Mcclelland's Motivational Needs Theory. Retrived from www. businessballs. com> leadership/management 20, 4-12.

McClelland, D. C. (1987). Human motivation. CUP Archive.

Nohria, N., Groysberg, B., and Lee, L. (2008). Employee motivation: A powerful new model. Harv. Bus. Rev. 86, 78. 
Olcum, D., and Titrek, O. (2015). The effect of school administrators' decision-making styles on teacher job satisfaction. Procedia-Social Behav. Sci. 197, 1936-1946.

Ottenbacher, M., and Harrington, R. J. (2007). The innovation development process of Michelin-starred chefs. Int. J. Contemp. Hosp. Manag. 19, 444-460. doi:10.1108/09596110710775110.

Padmala, S., \& Pessoa, L. (2010). Interactions between cognition and motivation during response inhibition. Neuropsychologia, 48(2), 558-565.

Patterson, M., Warr, P., and West, M. (2004). Organizational climate and company productivity: The role of employee affect and employee level. J. Occup. Organ. Psychol. 77, 193-216.

Polatcan, M., and Titrek, O. (2014). The relationship between leadership behaviors of school principals and their organizational cynicism attitudes. Procedia-Social Behav. Sci. $141,1291-1303$.

Porter, L. W., and Lawler, E. E. (1968). Managerial attitudes and performance.

Rahmana, A. S., Haryoko, U. B., \& Kurniawan, A. F. (2020). The Effect Of Giving Incentives, Work Facilities And Work Discipline On Sales Productivity At PT. Gramedia Asri Media Business Unit To Business Wholesale Jakarta. HUMANIS (Humanities, Management and Science Proceedings), 1(1).

Rao Subba, P. (2005). Essential of HRM \& Industrial Relationships. Pg (480 to 482).

Rizky, M. C., \& Ardian, N. (2019). Enhance employee performance for increase work motivation on universitas pembangunan panca budi medan. Journal Homepage: http://ijmr. net. in, 7(08), 19-34.

Salleh, F., Dzulkifli, Z., Abdullah, W. A. W., and Yaakob, N. H. M. (2011). The effect of motivation on job performance of state government employees in Malaysia. Int. J. Humanit. Soc. Sci. 1, 147-154.

Schulz, S., and Steyn, T. (2003). Educators' motivation: Differences related to gender, age and experience. Acta Acad. 35, 138-160.

Shahzadi, I., Javed, A., Pirzada, S. S., Nasreen, S., and Khanam, F. (2014). Impact of employee motivation on employee performance. Eur. J. Bus. Manag. 6, 159-166.

Shanks, N. H. (Ed.). (2016). Introduction to health care management. Jones \& Bartlett Publishers.

Shin, Y., \& Hur, W. M. (2021). When do job-insecure employees keep performing well? The buffering roles of help and prosocial motivation in the relationship between job insecurity, work engagement, and job performance. Journal of Business and Psychology, 36(4), 659-678.

Springer, G. J. (2011). A study of job motivation, satisfaction, and performance among bank employees. J. Glob. Bus. Issues 5, 29.

Sun, K. (2016). The power of perks: equity theory and job satisfaction in Silicon Valley.

Taohid, M. G. R., Sujai, R. A. D. A., \& Nugraha, N. M. (2021). Does work discipline affected by the working environment and work motivation?. Economics. Ecology. Socium, 5(1), 13-23.

Tasman, T., Siregar, Z. M. E., \& Nasution, M. F. (2021). The Influence of Work Environment, Promotion, and Job Satisfaction on Employee Performance. Budapest International Research and Critics Institute (BIRCI-Journal): Humanities and Social Sciences, 4(3), 4026-4031.

Titrek, O. (2009). Employees' organizational justice perceptions in Turkish schools. Soc. Behav. Personal. an Int. J. 37, 605-620. 
Titrek, O. (2015). The level of innovation management of school principals' in Turkey. Anthropol. 19, 449-456.

Trank, C. Q., Rynes, S. L., and Bretz Jr, R. D. (2002). PREFERENCES AMONG HIGH ACHIEVERS. J. Bus. Psychol. 16.

Trevor, C. O., Gerhart, B., and Boudreau, J. W. (1997). Voluntary turnover and job performance: Curvilinearity and the moderating influences of salary growth and promotions. J. Appl. Psychol. 82, 44.

Trotter, R. G., Zacur, S. R., and Stickney, L. T. (2017). The new age of pay transparency. Bus. Horiz. 60, 529-539.

Trout, J. D. (2017). Motivation and the sense of understanding in theory construction. Motiv. Sci. 3, 304.

Uka, A. (2012). Motivational factors of Albanian graduate students pursuing a master degree in education. Beder Univ. J. Educ. Sci., 15-23.

Veloso, C. M., Sousa, B., Au-Yong-Oliveira, M., \& Walter, C. E. (2021). Boosters of satisfaction, performance and employee loyalty: application to a recruitment and outsourcing information technology organization. Journal of Organizational Change Management.

Vlãdescu, I. (2014). Setting goals for career: from career planning to career management. Alma Mater Univ. J. 7, 12-16.

Vozza, S. (2018). This is how Google motivates its employees. Retrieved May 4, 2019.

Vroom, V. (1964). Expectancy theory. Work Motiv.

Wang, L., \& Tian, L. (2012). Affinity and Tacit Knowledge Management in Project Team. J. Softw., 7(9), 2149-2157.

Wiley, C. (1997). What motivates employees according to over 40 years of motivation surveys. Int. J. Manpow. 18, 263-280. doi:10.1108/01437729710169373.

Zahaj, M., Saliaj, A., Metani, L., Nika, S., \& Alushi, E. (2016). Factors related to job satisfaction among nurses. European Scientific Journal, 12(5). 